\title{
King Richard III: How a Man Becomes a Monster
}

\author{
Angelina Thompson \\ College of Liberal Arts \& Sciences \\ Faculty mentor: Florin Curta, Department of History
}

\begin{abstract}
History is notorious for being written by the victors, often to the detriment of truth. The losers are usually portrayed as small and insignificant to the course of history. However, such erasure can happen to the greatest and most influential people, even kings. King Richard III is perhaps one of the most infamous kings to wear the English crown. He has been depicted as a ruthless, power hungry villain by famous humanists such as Thomas More, and immortalized as a deformed monster by William Shakespeare. For over five hundred years, historians have commonly agreed with More's and Shakespeare's verdicts. It was not until recently that supporters of Richard took up the king's case to truly examine the evidence against him. Some historians now see Richard, not as evil monster, but as man responding to a political crisis. Less clear, however, is the process by which the image of Richard III as England's 'Black Legend' actually came into being. In this paper, I intend to trace the origin of that extremely negative assessment of both the man and his reign. My goal is to show how the image of King Richard as a monster is largely a literary construct by analyzing contemporary and modern sources.
\end{abstract}

\section{Introduction}

English history is fraught with controversies, murders, betrayals, and lies; no other period is as guilty of this as the Wars of the Roses. The conflict between the White Rose of York and the Red Rose of Lancaster, known as the Wars of the Roses, is infamous for being a time of vicious civil war in fifteenth-century England. This dispute is what brought about the tyrannical rule of Henry VIII and the Golden Age of Elizabeth I. However, thirty years before the Tudors ascended the English throne, the Yorks and the Lancasters turned English soil red as they fought each other for supremacy. Of particular interest is the last three years of the Wars' duration.

After the death of Edward IV in 1483, governance of the realm came into question. Left to rule in his place was twelve-year-old Edward V, who needed a regency because he was a minor. Two factions formed: one for Edward's mother's family, the Woodvilles and one for Richard Duke of Gloucester, Edward IV's brother and Edward V's uncle. The Woodvilles were much hated by the English nobility as they were perceived as upstarts. According to one source, Edward IV's final wish was for his brother Richard to assume the Protectorate of the country and serve as regent 
until his son came of age. ${ }^{1}$ As Richard was not with the new king at the time of Edward IV's death, the Woodvilles moved to secure Edward V into their possession. The events following the death of Edward IV led to Richard, Duke of Gloucester, seizing the crown, the disappearance of Prince Edward V and his brother, and the final fall of the house of York.

The reign of King Richard III is possibly the most controversial of all English monarchs. His supposed usurpation of his nephew's throne has inspired many, from historians to playwrights, to take up the case of Richard III to try to uncover the motives and nature of the man called monster. The former Duke of Gloucester has been accused of treachery, murder, greed, and even incest, usually for the benefit of the Tudor Dynasty which thrived off of Richard's fall. The contemporary sources covering his reign are not entirely reliable as their creators were too far removed from the events either in location or in time, which complicates the discussion of Richard's character and reputation. Additionally, sources often closest in time to Richard's reign, in particular that of Sir Thomas More, is suspect because of the pressure applied by Henry VII in order to justify his conquest of the English throne.

Over the centuries, Richard's reputation has changed drastically from the grotesque, hunchbacked tyrant of Sir Thomas More and William Shakespeare, to a flawed man, who came to power in violent and troubled times. This development is due to many factors, the most important being the availability of new evidence - in the form of documents newly made public and the changing of cultural attitudes. ${ }^{2}$ This paper will follow the evolution of King Richard III's reputation from its creation during his reign to the modern day using contemporary sources from Richard's lifetime as well as pop culture influences from the twenty first century. My intent is not to prove Richard's innocence or guilt, but to gather an understanding of how public opinions and accusations can turn a man into a monster.

\section{Creation and development}

\section{From Duke to King}

The discussion of Richard III's reputation goes back to the beginning of his brother's reign. Even though none of the contemporary sources were present for those events, many of them claim to be knowledgeable of the Duke of Gloucester's actions. One such example is Philippe de

\footnotetext{
${ }^{1}$ David Horspool. Richard III: A Ruler and his Reputation. (London: Bloomsbury, 2017): 149.

2 Jeremy Potter Good King Richard?: An account of Richard III and his Reputation. (London: Constable, 1996).
} 
Commynes of France, who was Prime Minister to Louis XI from 1472 to 1477. In his Memoirs, Commynes accuses Richard of murdering Henry VI:

King Henry [VI] was a very ignorant and almost simple man and, unless I have been deceived, immediately after the battle [Tewkesbury] the Duke of Gloucester... who later became King Richard, killed this man with his own hand or at least had him killed in some obscure place. ${ }^{3}$

This alleged murder is one of the greater crimes placed and held against Richard. It is important to note that Commynes wrote this allegation in 1490 - over a decade after the events took place - and on the basis of rumors, as he himself probably never stepped foot in England. Even though Henry VI was an ineffective king, he was much loved by the people, making these accusations against Gloucester all the worse. Not only was Commynes not present during the actual events, but there is no actual evidence that Richard was responsible for Henry VI's death.

The previous accusations were only made after Richard became king, before such time he had few enemies. It was not until Edward IV's death that any issues with Richard came to light. After the old king's death, the two major power factions scrambled to gain control over Edward V in order to secure control of the country. According to Dominic Mancini, an Italian who visited England from 1482 to mid 1483, Edward IV had specifically named Richard Protector for his son's minority. ${ }^{4}$ (Mancini's accounts are crucial to understanding the development of Richard's reputation because he was one of a select few who was actually present for these events.) However, the Woodvilles and Richard had a troublesome past and, therefore, did not want the other in charge of the country's government. The Woodvilles got to Edward V first, but Richard was close behind. After a seemingly pleasant dinner together, Richard and his new ally Warwick, the Duke of Buckingham, arrested the Woodville party and took control of the young king.

It is this moment that many hostile to Richard claim signifies that he was already looking further than the Protectorate. One such source is the Crowland Chronicle. The Crowland Chronicle is a mysterious source, the second and third continuations concentrating on Richard's reign. The author of this work is hitherto unknown, although it is theorized that it could have been the work of John Russell, who was Richard's chancellor, or someone in his retinue. The Chronicler believed that Gloucester was "methodically clearing a path to power.". He claimed

\footnotetext{
${ }^{3}$ Ibid., 79.

${ }^{4}$ Horspool, 149.

${ }^{5}$ Ibid., 152.
} 
that Richard was forbidding anyone to come near the king on pain of death, and that he was "commanding and forbidding everything like another king." ${ }^{6}$ Despite the Chronicler's comments, most people at the time still trusted Richard.

After taking the reins of government in May, Richard postponed Edward V's coronation for the second time. While these actions were somewhat suspicious, most were unconcerned until the events of June $13^{\text {th }}$. On this fateful day, Richard called half the council to the Tower of London and arrested Lord Hastings, Thomas Rotherham, and John Morton. These arrests came seemingly out of the blue, as Hastings was previously a close ally to Richard and a very powerful man. Richard claimed that Hastings was part of a plot engineered by the Woodvilles for his destruction and had him almost immediately executed without a trial. Gloucester's seemingly sporadic and lethal behavior on this day would fuel many misgivings about his character. The Crowland Chronicler believed that these executions were to be seen as an example:

The three strongest supporters of the new king being thus removed without judgements or justice, and all the rest of his faithful subjects fearing like treatment, the two dukes [Gloucester and Buckingham] did thenceforth as they pleased. ${ }^{7}$

Hastings' execution is considered by many to be murder because he was never tried and is one of the first concrete instances that provides some basis for Richard's reputation as a vicious tyrant. It is within these events that the tide of public opinion begins to turn against the king.

Richard's next move was shocking and, to some, made his intentions abundantly clear.

On June $22^{\text {nd }}$, a sermon was preached at St. Paul's Cross that claimed that Edward IV's children were illegitimate because of a pre-contract Edward had with another woman. This claim barred the York children from the line of succession and deprived Edward V of his throne. The sermon went further and suggested that Edward IV, himself, was illegitimate, along with the second York brother Clarence, and that Richard was the sole legitimate son of Richard Duke of York. The sermon, therefore, declared that Richard had the best claim for the English crown. On June $26^{\text {th }}$ a committee from the English government put forth a petition asking Richard to "assume his lawful rights" and ascend the English throne. The Crowland Chronicler claims that this petition

\footnotetext{
${ }^{6}$ Richard III Society, "The Croyland Chronicle: Part VII The Third Continuation of the Croyland Abbey: January 1477 - June 1483 with notes." available at http:/www.r3.org/on-line-library-text-essays/crowland-chronicle/part-vii/ (visit March 7, 2018).

${ }^{7}$ Richard III Society, “The Croyland Chronicle: Part VII The Third Continuation of the Croyland Abbey: January 1477 - June 1483 with notes."
} 
was merely a pretext and that Richard claimed power and the English crown himself. ${ }^{8}$ Richard accepted the request, and, on the twenty-sixth of June, became King Richard III.

\section{The Reign of King Richard III}

Richard III went to the throne of England in triumph, with a grand coronation and celebration. Mancini's account of this day gives no impression that there was any public opposition to the king at the time. In fact, Richard's rise to power was presented as a blessing and as a "rescue of a kingdom from the ignominy of an illegitimate ruler.". 9 It is notable that not all contemporary sources concerning Richard's character were negative. Thomas Langton, newly made bishop of St. David's in Wales, wrote to a friend in September of 1483:

He [Richard] contents the people where he goes best that ever did Prince, for many a poor man that hath suffered wrong many days hath been relieved and helped by him and his commands in his progress... On my trouth I liked never the conditions of any prince so well as his; God hath sent him to us for the wele of us all.. ${ }^{10}$

While it is probable that Langton's favorable views are associated with him being recently appointed bishop, is clear that there were, in fact, people who were quite happy with Richard as king.

If this opinion was not widely shared at the beginning of his reign, then the rumors of the princes' disappearances in late August 1483 made it all the more rare. It was not until these rumors began circulating that people started objecting to Richard's reign. Philippe de Commynes declared that "the duke had his two nephews murdered and himself made king." ${ }^{11}$ Mancini claims to have heard from the physician Augustine, who was the last of Edward V's attendants, that Edward "like a victim prepared for sacrifice, sought remission of his sins by daily confession and penance, because he believed that death was facing him." ${ }^{12}$ These rumors spread far and fast as Guillaume de Rochefort, a lawyer who served as chancellor under Louis XI and Charles VIII of France, warned the Estates General of the events in England:

\footnotetext{
${ }^{8}$ Richard III Society, “The Croyland Chronicle: Part VII The Third Continuation of the Croyland Abbey: January 1477 - June 1483 with notes."

${ }^{9}$ Horspool, 175 - 176.

${ }^{10}$ Peter Hammond, “The Reputation of Richard III" Richard III: A Medieval Kingship, edited by John Gillingham (London: Collins \& Brown, 1993): 134.

${ }^{11}$ Sharon D Michalove, "The Reinvention of Richard III" The Ricardian: Journal of the Richard III Society 10, 130: 271.

${ }^{12}$ Potter, 83.
} 
Think, I beg you, what happened in that land [England] after the death of King Edward, that his children already grown up and remarkable, were killed with impunity, and the royal was passed, with the people's blessing, to their killer. ${ }^{13}$

That being said, not all contemporary sources accuse Richard of this particular crime. The Crowland Chronicler believed the rumors of the princes' murders were only spread to hurt Richard's reputation, not because he actually had them killed.. ${ }^{14}$ It is also important to understand that Rochefort's opinions were not shared with the general population, but with the few elite in France. However, this information does show that people outside of England were beginning to form a negative opinion of Richard. Most believed, at the time and today, that Richard was either personally responsible or knew of the princes' murders. No matter the belief, these rumors caused much distrust in Richard III and were the catalysts in his fall from power.

It was also in August 1483 that Henry Tudor, the obscure, exiled Earl of Richmond, arrived on the scene. In order to assert his claim over the English crown, Henry would need to earn the love of the public, which meant turning them against Richard. Additionally, Henry's mother, Margaret Beaufort, and the Dowager Queen Elizabeth Woodville joined forces to overthrow Richard by betrothing Henry to Edward IV's eldest daughter Elizabeth of York. Elizabeth was living under Richard's care at the time and by 1484 was making many appearances at court. It seemed to some that Richard and Elizabeth were getting far too close. At Christmas time that year, the Crowland Chronicler comments that "rumors began to spread that Richard meant to marry his niece [Elizabeth], either after the death of the queen, or by means of a divorce for which he believed he had sufficient grounds." 15 To make matters worse, Queen Anne's untimely death led some to believe that Richard had her poisoned in order to hasten his marriage to Elizabeth. Rumors and popular opinion got so negative that later that month the king was forced to publicly deny any such intentions. Though publicly denied, these allegations of incest have followed Richard and harmed his reputation to this day, and are even romanticized by modern novelists.

\footnotetext{
${ }^{13}$ Horspool, 181.

${ }^{14}$ Potter, 75.

${ }^{15}$ Richard III Society, “The Croyland Chronicle: Part VIII The Third Continuation of the Croyland Abbey: July 1483 - March 1485 with notes," available at http://www.r3.org/on-line-library-text-essays/crowland-chronicle/partviii/.
} 


\section{The Battle of Bosworth Field}

The events before, during, and after the battle at Bosworth are still shrouded in mystery, yet are crucial in the solidification of Richard's reputation at the time. His final moments would be immortalized in many forms and even praised by critics in later centuries. ${ }^{16}$ The first written account documenting what allegedly happened at the Battle of Bosworth Field was a Welsh poem in 1485. The lyricist was bard and prognosticator Dafydd Llwyd, who was supposedly consulted by fellow Welshman Henry Tudor just before the battle. This poem was written so recently after the battle's end that news of its outcome had not spread yet. Llwyd is pleased with Richard's death as he deserved it for murdering Edward IV's sons. The poem also accuses Richard of murdering "the saint" Henry VI. His death was a long time coming according to Llwyd, as "In time God above sends // The vengeance where it is due.". ${ }^{17}$ What is most interesting about the poem is the line where he refers to Richard as the "hound slaughtered in the ditch," when Richard was, in fact, thrown into a quickly dug hole and buried like a dog. How Dafydd Llwyd knew of this is unknown and it may have simply been a literary technique and not a specific reference to the event.

As this poem shows, Richard's reputation had changed drastically by the time of his death. Before the rumors of the young princes' deaths, most people were unbothered by Richard, particularly the common people. It was concern over the princes' wellbeing and the introduction of a rival claimant for the throne that allowed for Richard's reputation to disintegrate. Once it was clear that Richard III was dead and that a new dynasty had begun, there was no one to stand up for him. Henry VII would use authors such as the lawyer Sir Thomas More to further his agenda as the new king.

\section{Sir Thomas More}

The reign of King Henry VII was not kind to Richard. It was during this time that wild stories about him were spread by notable authors and historians. It is not at all surprising that Henry would want to encourage this hatred. Henry's claim to the throne was tenuous at best - his mother could trace her bloodline to a bastard grandson of Edward III. Henry, therefore, needed to bolster his claim as much as he could, as he did not want to rely utterly on his marriage to Elizabeth of York. Additionally, Henry faced other insurrections during his reign, so a hated

\footnotetext{
${ }^{16}$ Peter Hammond, 138.

${ }^{17}$ Andrew Breeze, “A Welsh poem of 1485 on Richard III” Richard III Society 18 (2008): 2.
} 
Richard would prevent any insurgences on his behalf. To accomplish this, Henry encouraged respected authors to collect accounts of Richard's reign, and, essentially, recount those events in a way that strengthened his claim to the throne. One such author, and respected lawyer, was Sir Thomas More.

Thomas More is arguably the most influential person in the development of Richard's reputation. The caricature image of Richard III was created by More in his History of King Richard III. More uses incredible, sometimes unbelievable, detail to tell the story of Richard's usurpation of the crown and the murder of the princes. More supposedly retrieved the information for his text from people who were alive during Richard's reign, but not necessarily those who were present during the events discussed. Essentially, much of what More records is merely hearsay, not actual fact. Additionally, he relies heavily on the memories of aging people, which cannot be considered entirely reliable sources.. ${ }^{18}$ This incredibly important detail is often overlooked because of More's reputation as a reputable lawyer and, particularly, his status as a martyr.

One of More's more significant contributions to Richard's battered reputation is the fabrication of the king's deformities. His History of King Richard III is the first source that mentions Richard having any physical abnormalities:

[Richard was] little of stature, ill fetured of limmes, croke backed, his left shoulder much higher than his right, hard favoured of visage... he was malicious, wrathful, envious, and, from afore his birth, ever frowarde. ${ }^{19}$

If Richard had such noticeable deformities, surely one of the many contemporary sources would have mentioned them. Instead, the only evidence Richard's physique was out of the ordinary were the many comments about his short stature, which he evidently inherited from his father. Even after Richard's body was striped naked and paraded about, there were no rumors of deformities. It was not until four decades later that More made his claims. Despite the lack of evidence, More was firmly believed for centuries and Richard III's transformation from a fallen king into a monster began.

\footnotetext{
${ }^{18}$ Philip Schwyzer, "Lees and moonshine: remembering Richard III, 1485 - 1635” The Renaissance Quarterly 63 (2010): 856.

${ }^{19}$ Sir Thomas More, Utopia and King Richard III, edited by Gilbert Burnet (Boston: Hillard, Gray. 1834): 193.
} 
More also paid special attention to the events of June $13^{\text {th }}$, the day Richard arrested and executed Lord Hastings. In his History, More includes extreme details such as dialogue, that he could have had no way of knowing. He reports that the king was in a seemingly good mood one moment, left the room, and then returned in anxious distress. More also claimed to have known that Richard kept playing with his dagger as he paced about the room speaking of treason.. ${ }^{20}$ Even if More had spoken to someone who was in the room, it is unreasonable to suppose that anyone could remember in perfect detail all that was said and done. More's retelling of the events, of Richard's entire reign, should be considered more of a dramatic treatise against tyranny than actual history... ${ }^{21}$

More also writes in an odd amount of detail about the murders of Prince Edward and Prince Richard. He claims to have heard the confession of one of Richard III's former servants, Sir James Tyrrell. In this confession, Tyrrell purportedly admits to having the boys smothered and then buried under a flight of stairs in the Tower of London, under the orders of King Richard. ${ }^{22}$ Sir James Tyrrell was arrested by Henry VII in 1501 for unrelated charges. If Tyrrell had confessed to the murder of the princes, then surely Henry would have announced the fact and put an end to any current or future pretenders, but no such proclamation was made. In fact, the only source to claim Tyrrell made any mention of the princes is Thomas More, suggesting, once again, that More was simply repeating hearsay. However, whether or not More used credible sources, the fact remains that Thomas More's interpretation of Richard essentially constructed his image as a monster that inspired William Shakespeare's famous play and has spoiled Richard's reputation for centuries.

\section{William Shakespeare}

William Shakespeare is arguably the most famous playwright in history. He is best known for his pieces such as Romeo and Juliet, Hamlet, and Othello, but is also author of Richard III. Shakespeare first mentioned Richard in his Henry VI Parts II and III. He describes Richard as a "heap of wrath, foul indigested lump, as crooked in thy manners as thy shape.". ${ }^{23}$ The deformed,

\footnotetext{
${ }^{20}$ More, 243.

${ }^{21}$ Hammond, 138.

${ }^{22}$ Howard B Norland "More's Recreation of History in His Richard III' Journal de la Renaissance Vol. IV (2006): 190 .

${ }^{23}$ William Shakespeare, Henry VI: Part II, (1623), available at http://shakespeare.mit.edu/2henryvi/full.html. (visit March 7, 2018).
} 
hunchbacked Richard III was created by More but immortalized by Shakespeare. He has Richard kill the Duke of Somerset at the first battle of the Wars of the Roses at St. Albans. This is a significant addition as, in actuality, Richard was only two years old at time. This marks the first instance of Shakespeare embellishing historical facts for dramatic purposes. In Part III of Henry VI, Richard helps his brothers Edward and Clarence kill Henry VI's son. Richard is also the one to mortally stab Henry. Even though Shakespeare was writing a play specifically meant for entertainment, many writers for generations after took his word as historical evidence.

Shakespeare decided that Richard needed his own play, so in 1593, he wrote Richard III. He wastes no time developing the king's character as a monster:

Cheated of feature by dissembling nature, Deform'd, unfinish'd, sent before my time Into this breathing world, scarce half made up, And that so lamely and unfashionable That dogs bark at me as I halt by them; Why, I, in this weak piping time of peace Have no delight to pass away the time, Unless to spy my shadow in the sun And descant on mine own deformity: And therefore, since I cannot prove a lover, To entertain these fair well-spoken days, I am determinéd to prove a villain And hate the idle pleasures of these days.. ${ }^{24}$

Shakespeare immediately establishes Richard's character as bitter, malicious, mischievous, and, most importantly, deformed. He demonstrates that Richard is not a character to root for and that he will be the antagonist of the story.

Historical fiction is a well-known genre of literature nowadays, however, in Shakespeare's time, no such genre existed. Historical facts were not necessarily available to the average person, so the only outlet through which common people could hear news or learn history from was hearsay, or in this case, theatre. The audience had no way of knowing that what they were watching was grossly dramaticized. As a result, the character of Richard III in Shakespeare's play became synonymous with the real King Richard, much to the detriment of his reputation.

By the middle of the seventeenth century, a specific image of Richard III had developed, and "the facts of his real appearance, character, and deeds had been buried under a great mound of

\footnotetext{
${ }^{24}$ William Shakespeare, Richard III (1593) Act 1, scene 1, 11.
} 
tradition." ${ }^{25}$ At this point in history, the facts no longer mattered, if they ever had. Richard's reputation as monster-tyrant was firmly established. To make matters worse, Shakespeare had no solid sources from which to draw material. By the time he wrote the play, few, if any, people who lived through Richard's reign were still alive. Even if there were survivors, they would have been over a hundred years old, and their memories would have been less than reliable. ${ }^{26}$ As previously stated, Shakespeare did not pay particular attention to historical detail as his intention was not to educate but to entertain. By the end of the sixteenth century, Richard was fading from living memory, which allowed Shakespeare to reconstruct him on a fantastical scale. With no one bothering, or caring, to check facts, the English people readily absorbed Shakespeare's portrayal of Richard and passed on this new image to the next generation. These very themes and portrayals of Richard would continue on through popular opinion, despite opposing views, to the modern day where authors and directors would adapt More's and Shakespeare's version of events to the big screen.

\section{Evolution}

\section{Richard and Pop Culture}

In the nineteenth and twentieth centuries, Richard reached the world through historical fiction. In 1951, mystery novelist Josephine Tey published The Daughter of Time, which tells the story of a modern police officer's investigation of Richard III's crimes. In the end, Richard's reputation as a murderer is credited to Tudor propaganda. In contrast, Laurence Olivier appeared on the silver screen as the king in the 1955 film adaptation of Shakespeare's Richard III. Olivier's performance brought Shakespeare's hunchbacked Richard to life and reinforced the traditionalist views of the long dead king. This portrayal is still used today to represent Richard. Despite the development from the "Morean" view to the revisionist view in scholarly circles, society still enjoys a wicked king over a saintly one.

In the twenty-first century, it is Philippa Gregory who dominated the construction of Richard's popular image. Her series of Plantagenet-based novels, the first of which was published in 2009, paints quite a different picture from Olivier's performance. Gregory is a notorious Yorkist, someone who favors the Plantagenet cause over the Lancastrian, and makes no attempt to hide it. In her novels, Richard is a fallen hero and is even given a tragic romantic storyline with his

\footnotetext{
25 Hammond, 140.

${ }^{26}$ Schwyzer, 862.
} 
niece, Elizabeth of York. ${ }^{27}$ Gregory's stories have recently been adapted for television in The White Queen (2013) and The White Princess (2017). If Richard was once victim of Tudor propaganda, under Gregory, Henry Tudor is victim of Yorkist propaganda. Gregory is notoriously controversial for this reason and also because she claims to be greatly committed to historical accuracies. This claim is almost comical as she has Richard and Elizabeth in an incestual relationship, which is presented as positive, and has Margaret Beaufort murder Edward $\mathrm{V}$ and his brother. These gross inaccuracies often go unnoticed by causal audiences as they do not necessarily have a background in the actual historical events. This means that while the image of Richard being portrayed to modern audiences is the complete opposite of Shakespeare's, it is equally far from the truth.

As these interpretations are fairly new, existing for less than a decade in Gregory's case, they are still under researched and analyzed by scholars. New content is being produced so rapidly that it can be difficult to keep up. What is important to take away from this is that people are still very much interested in Richard. As the $19^{\text {th }}$ century progressed, the move favorable view of Richard began to be the most popular, as is represented through pop culture today. Richard's story has become more available to popular audiences as he was the subject of film and historical novels. Moderate viewpoints are also on the rise and historians are more readily accepting the idea of Richard existing in a grey area. As society in general becomes more accepting of flawed individuals, he is being understood more as a flawed human rather than a legendary figure of evil. That being said, he is also being portrayed on television as a fallen hero, which is just as incorrect as Shakespeare's monster.

\section{Conclusion}

King Richard III is one of the most notorious kings England has ever known. The start of his reign was steeped in controversy and scandal. Usurpation is not uncommon in Medieval history, but the simple fact that Richard took the English crown from his underage nephew, who soon after disappeared, infuriated many then and now. Before Edward IV's death, Richard was his brother's right-hand man, carrying out any order he was given. But after April 9, 1483, Richard made risky political decisions that changed the course of history.

History is written by the victors, and the victors were the Tudors. Because Henry won the crown, Sir Thomas More created a new reputation for Richard as a suspicious, conniving tyrant

\footnotetext{
${ }^{27}$ Philippa Gregory, The White Queen: The Plantagenet and Tudor Novels Book 1 (New York: Touchstone, 2009).
} 
with a hunchback. Their image was solidified and further dramatized by William Shakespeare, and Richard was transformed from an average tyrant into a hideous monster. As the Tudor dynasty came to a close, Richard's reputation was set, and even as progress is made, many still believe these tales.

The Richard shown in popular media today is just as fictional as the Richard in Shakespeare's play. Believing that he was either as Shakespeare or Philippa Gregory portrayed him completely ignores not only the evidence, but also the reality of being human. In the current climate, society is more accepting, not to mention more interested, in heroes and leads that reside in the grey areas of morality, instead of purely black or white. Richard's reputation has improved significantly simply because more and more people are willing to accept that no one is all good or all bad. Society in general is now more forgiving of human nature and can even find entertainment and reassurance in seeing their heroes have flaws. As time goes on, hopefully more historians and thinkers will come to understand this, as well. More importantly, perhaps both Traditionalists and Ricardians can learn to keep an open mind and not let bias get in the way of the truth.

\section{Bibliography}

Breeze, Andrew. “A Welsh Poem of 1485 on Richard III," Richard III Society no. 18 (2008).

Gregory, Philippa. The White Queen: The White Queen: The Plantagenet and Tudor Novels Book 1 (New York: Touchstone, 2009).

Hammond, Peter. "The Reputation of Richard III” Richard III: A Medieval Kingship, edited by John Gillingham (London: Collins \& Brown, 1993).

Michalove, Sharon. "The Reinvention of Richard III" The Ricardian: Journal of the Richard III Society 10, no. 130 (1995).

Horspool, David. Richard III: A Ruler and his Reputation. (London: Bloomsbury, 2017).

More, Thomas. Utopia and King Richard III, edited by Gilbert Burnet (Boston: Hillard, Gray. 1834).

Norland, Howard. "More's Recreation of History in His Richard III' Journal de la Renaissance Vol. IV (2006).

Potter, Jeremy. Good King Richard?: An account of Richard III and his Reputation. (London: Constable, 1996). 
Richard III Society, "The Croyland Chronicle: Part VII The Third Continuation of the Croyland Abbey: January 1477 - June 1483 with notes," available at http://www.r3.org/on-line-library-text-essays/crowland-chronicle/part-vii/.

Richard III Society, "The Croyland Chronicle: Part VIII The Third Continuation of the Croyland Abbey: July 1483 - March 1485 with notes," available at http://www.r3.org/on-line-library-text-essays/crowland-chronicle/part-viii/.

Schwyzer, Philip. "Lees and moonshine: remembering Richard III, 1485 - 1635" The Renaissance Quarterly no. 63, (2010).

Shakespeare, William Henry VI: Part II, (1623), available at http://shakespeare.mit.edu/2henryvi/full.html.

Shakespeare, William. Richard III (1593). 